\title{
Trichotomy of Relation Through Instrumental Communication in Pre-Adjudication Stage: The Failure of Criminal Procedure Code to Foster Law Enforcement Attitudes
}

\author{
Rocky Marbun \\ \{rocky_marbun@univpancasila.ac.id\} \\ Faculty of Law, Pancasila University, Jalan Srengseng Sawah, Jakarta, Indonesia
}

\begin{abstract}
The main objective of the existence of the Criminal Procedure Code is to provide guidance to the attitude of law enforcers in carrying out their duties and functions based on authority. However, in the trial process in the pre-adjudication domain, often the National Police Investigators and Public Prosecutors have an attitude that creates losses for someone who has the status of a suspect or defendant in defending his / her rights. The purpose of this research is to reveal the mode of behavior of the National Police Investigator and Public Prosecutor which harm the suspect or defendant in the pre-adjudication stage. This study uses a semiotic approach and critical discourse analysis to complement the legal research methods. The results of this study intend to show the existence of an instrumental communication model based on the trichotomy of the relation to prevent the suspect or suspect from being able to defend.
\end{abstract}

Keywords: Relationship Trichotomy; Instrumental Communication; Police investigator; Public Prosecutor

\section{Introduction}

A criminal justice system, in essence, is a movement that is dynamic and connected from all its supporting components and sub-components in realizing the objectives of law, in particular, and the goals of the nation and state in general. However, it has become common sense that when there is a discourse on the criminal justice process, there has been a limitation only on the criminal procedural law. In fact, according to Luhut MP. Pangaribuan[1], the discourse on criminal procedural law is only a small part of a complete system and is only normative in nature relating to procedures. Meanwhile, in a broad sense, a criminal justice system is actually a social system, which can be approached with various approaches, although later, Muladi[2] closes his opinion by saying that it is a social system which describes that in formulating and responding to criminal behavior involving all elements of society.

In fact, Muladi is not alone, this view is also a grand narrrative in the law enforcement system in Indonesia, because almost all legal scientists and legal practitioners would say so. So, it is the community who is the focus of study in various kinds of legal studies. Therefore, there is an opinion put forward by Andi Yuliani[3], that law was created to regulate the state system and has a role as guardian of order in society. The researcher tries to further assert, that 
in fact, legal fiction "as if" directs its function only to emphasize the obedience of society to the law which has acquired its positive form.

As a result, law enforcers are a binary opposition to "the other" when a study is directed at the law enforcement process in implementing a trinity of law enforcement, namely values, norms, and behavior patterns [4]. Even if there were, studies on law enforcement were only based on the discrepancy between das sollen (what should have been) and das sein (what happened). Thus, it only focuses on the inaccuracy of the model of interpretation of a legal norm on concrete facts.

In the end, legal science is trapped in 6 (six) principles as an irrefutable grand narrative, as stated by Bekti Suharto [5], namely value-free law, the purpose of law is certainty, linearity, liberation of non-legal elements, a hierarchical system of positive norms, and purification of legal science. These six principles are common sense logic in law and law, thus ignoring other perspectives. Thus, the legal community becomes a one-dimensional society, which, according to Marcuse, is a society in which all aspects of life are directed towards one goal [6]. According to us, it is a normative legal society.

In fact, when we try to examine the legal literature, we will find the views of Paul Scholten [7] and E. Utrecht [8] which explicitly require interdisciplinary research. This is based on a view of the law as an open system, in which explaining social reality is not possible with just one rule. Therefore, each regulation will be interconnected internally (innerlijke samenhang) in an open legal system (Open system van het recht). In my opinion, these two views are an entry point to be able to conduct studies in an interdisciplinary and multidisciplinary manner, although they are still based on legal norms.

The Criminal Procedure Code, referring to the Consideration of letters a and c, is a paradigm of thinking in interpreting all legal norms in procedural law which is comprehensive enough to be used as a basis for analysis of the trinity of law enforcement. The Criminal Procedure Code has normatively affirmed that the purpose of its enactment is for the public to understand their rights and obligations as well as a form of normative rules that form the "attitude" of law enforcers based on their function and authority. This means that the Criminal Procedure Code is not only normative, but also has a sociological character.

There are not so many studies in Indonesia that examine the 'attitude' aspect of law enforcers, apart from experiencing gowerfen-sein against the common-sense logic that law is value-free - so it must rule out non-legal elements, and also show the entry of social science in explaining the genealogy of power from law enforcers as power holders who dominate and hegemony society. The same thing actually happened in other parts of the world, for example in America, where the shocking statements of Compo, Fisher, and Gregory emerged, that there were very few studies that examined the investigators' process of examining Witnesses, although there was quite a lot of research that discussed when it was related to Witnesses Child and Victim Witness. Furthermore, Compo, Fisher and Gregory [9] explained "it is surprising to find that only one US study has examined real-world investigative interviewing of adult witnesses.

Fisher, Geiselman, and Raymond (1987) analyzed a South Florida sample of 11 witness interviews conducted by police detectives. After an initial open-ended question, investigators across interviews typically moved onto a closed questioning style. Most crime relevant facts were therefore elicited via closed questions, leaving little room for witnesses to provide a free narrative. Investigators did little to assist witness recall, often interrupted witnesses, and rarely allowed for pauses."

The same thing also happened in Indonesia, which is often exposed to the media through several researches from NGOs, namely physical violence against the investigator, related to 
the behavior pattern of the investigator in carrying out an examination during the investigation stage. Where, through a limited survey using google form, some time ago and it has been published, there is communication behavior that is instrumental to the people being examined in the investigation. The survey, based on the question "How do investigators ask questions?", There are as many as (1). $14.3 \%$ of respondents who answered how to ask the question corner, (2). $14.3 \%$ of respondents who answered investigators stated that they did not believe in the witness' answer, and (3). 71.4\% of respondents answered that the investigator's question led to what the investigator wanted [10].

In fact, when a survey question is directed to a question "Have you ever gotten a way of the Examiner in asking questions accompanied by an intonation change, which makes your client fear/stress?", Then some results answer (1) Yes, ever (71.4\%); and (2) Never (28.6\%) [10]. In this case, the investigator's behavior when carrying out an examination for the sake of the case file, did not actually commit physical violence, but did emphasize the instrumental communication side of the suspect.

The same thing also happened in the realm of prosecution, where according to $\mathrm{LBH}$ Jakarta, in the case experienced by Mustofa - a person accused of a criminal act, where the case has been declared complete (P-21) by the Public Prosecutor and has been delegated to the District Court, however Mustofa or his lawyer did not get the case file. In fact, starting from the level of investigation to prosecution, Mustofa did not get his right to get assistance from legal counsel [11].

Regarding the phenomenon of attitudes from the behavior patterns of law enforcers mentioned above, the researcher conducted a survey through the google form application to 92 respondents who work as Advocates which was carried out from 14 June 2020 to 14 July 2020, relating to the rights of suspects and defendants to obtain "case file". When answering the question "As a Legal Counsel, at the time of transfer of a case from the Public Prosecutor to the District Court based on Article 143 paragraph (4) of the Criminal Procedure Code, have you never received a case transfer letter simultaneously with submission to the District Court?"

To this question, the researcher provided 3 answers, namely Yes, No, and Often (estimated more than twice). Based on the choice of answers, the results obtained were $46.7 \%$ Yes answers, 32.6\% No answers, and 20.7\% Often answers (estimated more than two times). The diagram is as follows:

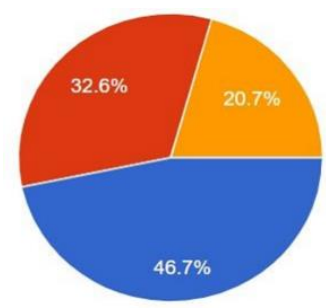

The fact of the attitude of other law enforcers, as disclosed by LBH Masyarakat in a consultation forum with detainees with the status of suspects or defendants - at the Jakarta Detention Center, where investigators attempted to frighten detainees, so they would not use legal services or lawyers, because will result in more severe punishment [12]. Based on the data above, the main question in this study is "what is the purpose of using an instrumental communication model that causes law enforcers to have an attitude that ignores their normative authority as stipulated in the Criminal Procedure Code?" 


\section{Research Method}

This research was conducted using legal research methods, however, in order to complement the research model, in addition to using the approach method commonly used in law, the researcher also used several social science-based approach methods, namely semiotic approach, discourse analysis approach. critical, relational trichotomy approach, and critical sociology approach. The use of the critical discourse analysis approach is because the data used is primary data in the form of communication texts both from online media and online surveys from Google Form to find language phenomena between law enforcers and investigators.

The relational trichotomy approach is used to trace power holders - in this case, law enforcers who have attribution authority use their power to produce knowledge. The trichotimi approach of relations has not been found in various social science literature, but this approach, construct researchers from Michel Foucault's Power Relations Theory, Jürgen Habermas' Theory of Knowledge-Interest, and Hegemony Theory of Antonio Gramsci. However, both the critical discourse analysis approach and the trichotomy of relations have the same goal of tracing the hidden interests of law enforcers. Pierre-Felix Bourdieu's critical sociological approach is used to detect the cause of the symbolic domination of law enforcers which results in several doxas that come from the process of absorbing certain values in a field as habitus.

\section{Analysis and Discussion}

Before getting into the core of the discussion in this study, the researcher will convey several doctrinal postulates as a consequence of using the Legal Research Method, namely:

a. The concept of Law Enforcement from Soerjono Soekanto[4] which explains that law enforcement is an effort to harmonize the values contained in norms and is reflected in the behavior of law enforcers through discretionary instruments.

b. J.A Pontier's legal discovery doctrine which emphasizes that an attempt to find law is, in essence, an act of public authority (government action, overheidshandelen) and is a monopoly of public authority (overheids monopolie) so that it can get help using force [13].

Based on the two postulates above, every legal interpretation used by law enforcement officials is, in essence, an action (discourse) that arises from the behavior of the play of powers by means of attribution (trinity of power) wrapped in free authority (discretion). ). Therefore, it is appropriate when the enactment of the Criminal Procedure Code has the aim of fostering an 'attitude' towards law enforcers that is directed towards normative obedience to the norms that emphasize it. That is, the attitude that gives rise to behavior patterns is an embodiment of the interpretation of law enforcers on attribution authority.

When the Criminal Procedure Code has explicitly stated that "attitude" is the main object of the regulation in the Criminal Procedure Code. Thus, Law is lacking in conceptual literature that explains 'what is attitude?'. According to Saifuddin Azwar[14], "attitude" as a concept has three components, namely:

a. The cognitive component is a component that shows the human ability to build an opinion on certain problems which are manifested in the form of attitudes; 
b. The affective component is a feeling that involves emotional aspects. This emotional aspect is usually the most deeply rooted as an attitude component and is the most enduring aspect of influences directed at changing one's attitude. Sometimes this component is likened to the feelings someone has for something; and

c. The behavioral component (conative) is an aspect of a certain tendency to behave in accordance with the attitudes a person has. And contains a tendency or tendency to act / react to something in certain ways. And with regard to the objects it faces, it is logical to expect that one's attitude is reflected in the form of behavioral tendencies.

In connection with this "attitude", in psycholinguistic studies and cognitive components, it is a result of processing between "the human mind" and "language"[15]. If, the researcher returns to the first postulate - from Soerjono Soekanto, then the truth-games are the result of the rationalization process between the trinity of power with values and norms and represented through practice language (parole). This means that legal science is unable to reach when there is a language game by law enforcement officials which is the result of its interpretation of legal norms.

Referring to the results of a survey via google form of 60 answers from 92 respondents who submitted answers to the investigator's refusal - based on Article 72 of the Criminal Procedure Code, and the Public Prosecutor - based on Article 143 paragraph (4) of the Criminal Procedure Code, to provide a copy (photocopy) of the suspect investigation case file and copies (photocopies) of complete case files and derivatives of Case Delegation Letters to the suspect / defendant, which give rise to language skills as a form of linguistic phenomena are as follows:

\begin{tabular}{|r|l|}
\hline 1. & Later in court \\
\hline 2. & Create a letter and wait for approval from the leadership. \\
\hline 3. & Throwing each other, investigators said they asked the public prosecutor and vice versa \\
\hline 4. & The reason is that the copy has not been given \\
\hline 5. & $\begin{array}{l}\text { When asking the investigator, he is told to ask the prosecutor, while the prosecutor is } \\
\text { told to ask the investigator }\end{array}$ \\
\hline 6. & Have many reason \\
\hline 7. & The reason for the short is clear and concise: it has not been photocopied. \\
\hline 8. & Secret \\
\hline 9. & $\begin{array}{l}\text { The reason is that the Legal Counsel will not want to be handed over to the judge when } \\
\text { he is in court. }\end{array}$ \\
\hline 10. & I'll ask through the judge \\
\hline 11. & Will submit an application for re-investigation and review of the rejected decision \\
\hline 12. & Just read it \\
\hline 13. & $\begin{array}{l}\text { Legal Counsels do not need to get an Investigation Report, because this is the } \\
\text { investigator's authority }\end{array}$ \\
\hline 14. & Later just ask for a copy to the replacement clerk \\
\hline 15. & Legal advisors are not entitled to receive an examination report \\
\hline
\end{tabular}




\begin{tabular}{|c|c|}
\hline 16. & $\begin{array}{l}\text { The legal attorney has no right to ask for an examination report for the entire } \\
\text { examination, only the right to request an official report on a special examination for the } \\
\text { suspect. }\end{array}$ \\
\hline 17. & Will be asked at the trial. \\
\hline 18. & Never \\
\hline 19. & We'll deliver \\
\hline 20. & Later not photocopied \\
\hline 21. & $\begin{array}{l}\text { It varies, there are those who claim to be asked to go to court and some say they will } \\
\text { be handed over to the suspect }\end{array}$ \\
\hline 22. & Later not photocopied \\
\hline 23. & $\begin{array}{l}\text { There are many reasons that don't make sense. However, what we often find is "later in } \\
\text { the trial, it will be submitted to the defendant or his attorney". }\end{array}$ \\
\hline 24. & Just go with the process \\
\hline 25. & Not allowed by the commander / superior \\
\hline 26. & $\begin{array}{l}\text { If we want to get a derivative of the examination report, then I as a legal attorney must } \\
\text { submit a request letter to the investigator or public prosecutor to his superior. }\end{array}$ \\
\hline 27. & All legal proceedings are carried out without notification to legal counsel. \\
\hline 28. & We'll give it. We'll ask the leadership first \\
\hline 29. & Promised to be given, but not in the end \\
\hline 30. & We are not obliged to provide derivative Examination Minutes to Legal Counsel \\
\hline 31. & Still in file preparation \\
\hline 32. & We'll tell the leadership first ... \\
\hline 33. & We'll ask the leadership first \\
\hline 34. & Derivatives to be requested in court \\
\hline 35. & $\begin{array}{l}\text { Actually, it is the obligation of the investigator and public prosecutor to give it, but } \\
\text { sometimes it must be asked for and sometimes it is difficult to give it for reasons that are not } \\
\text { clear. }\end{array}$ \\
\hline 36. & Write a letter, or later by judge \\
\hline 37. & Please go to court later \\
\hline 38. & $\begin{array}{l}\text { Later, the examination report has not been photocopied. You will come back here later, } \\
\text { but until the trial is not given a derivative of the Minutes of Investigation. }\end{array}$ \\
\hline 39. & There is still an investigation process and the file still needs to be refined \\
\hline 40. & We'll ask the leadership first \\
\hline 41 & Please go to court later \\
\hline 42. & Please go to court later \\
\hline
\end{tabular}




\begin{tabular}{|c|c|}
\hline 43. & $\begin{array}{l}\text { Asked for it at trial, but was not granted at the time of trial and took it at the } \\
\text { prosecutor's office. }\end{array}$ \\
\hline 44. & We'll ask the leadership first.. \\
\hline 45. & Investigator: later at the public prosecutor \\
\hline 46. & There are always many reasons \\
\hline 47. & Not ready, later \\
\hline 48. & Never got a definite comment about that \\
\hline 49. & Some are convoluted and some are evasive \\
\hline 50. & Accept it from court clerks only \\
\hline 51. & In order to make a request letter \\
\hline 52. & $\begin{array}{l}\text { Orally, he answered that there was no obligation to give to legal advisors, he had also } \\
\text { conveyed it verbally in a joking tone, the point was, there was no funds for photocopying the } \\
\text { files, never said that he had no time to follow up later. }\end{array}$ \\
\hline 53. & He said it was not in the criminal procedure code \\
\hline 54. & Wait for a judge's direction \\
\hline 55. & The reason is, later asking in court to ask the panel of judges at trial, Mr. lawyer... \\
\hline 56. & I'll be asked to go to court or ask the prosecutor's office \\
\hline 57. & $\begin{array}{l}\text { Please ask to the court, we have no obligation to provide a copy of the Minutes of } \\
\text { proceedings to legal counsel }\end{array}$ \\
\hline 58. & Everything is with the prosecutor, please coordinate with the prosecutor \\
\hline 59. & $\begin{array}{l}\text { Investigators are not professional, even though Article } 72 \text { of the Criminal Procedure Code } \\
\text { clearly states that the derivative of the BAP must be submitted to the family or through a } \\
\text { legal representative because the client's position is already a suspect. }\end{array}$ \\
\hline 60. & The reason is unfounded, it is still in the examination stage, later. \\
\hline
\end{tabular}

Based on such a communication model, it can at least be classified as follows:

a. The investigator does not wish to provide a derivative of the Audit Official Report, for various reasons that are not clear, one of which is waiting for the leadership's approval and an indication of a request for photocopies of money;

b. There is a phenomenon of shifting authority between investigators, public prosecutors and judges;

c. So, the Legal Counsel just ask the judge in court;

d. The investigator or the public prosecutor feels they have no obligation to provide;

e. The investigator or the public prosecutor feels that the request is not regulated in the Criminal Procedure Code;

f. Derivatives of BAP are Confidential. 
Sixth foregoing, it has become doxa both investigator and the public prosecutor when the request relates to the case file. Investigators and Public Prosecutors have self-awareness that violations of Article 72 KUHAP and Article 143 paragraph (4) KUHAP have no legal impact on them. Thus, the ability to process language based on the trinity of power raises the production of knowledge that case files are not obliged to be submitted to the Attorney and / or the Suspect / Defendant. Therefore, the request occurred in the field in the Police institution and in the Attorney General's Office. Thus, their positions as Investigator and Public Prosecutor are capital for them — based on power, to produce new knowledge on these provisions.

Likewise, when the researcher examines a doxa that is used as symbolic domination of detainees so as not to use legal counsel in the investigation process. This shows the use of power to produce a hegemony enforced knowledge. Up to this point, it has been clear that there is awareness in the investigator and public prosecutor that the trinity of power is a capital for him as a source of power to produce knowledge to achieve truth of games. This game pattern, as an attitude, has taken root in everyday life through the process of normalization as a habitus in them. Habitus like this, finds its articulation in language or communication activities. The text of the Law as a form of abstract values (langue) obtains articulation in the interpretation process, where power as capital based on its field has taken a role to produce knowledge as a new meaning to the norm in Article 72 of the Criminal Procedure Code and Article 143 paragraph (4) KUHAP.

This is as explained by Paul Ricoeur[16], where language activities in oral communication will create a direct communication model that brings along from the speaker's side, starting from the intonation aspect to gestures. In fact, as a "threatening" communication model it becomes necessary for the first interest, making the examinee focus on self-reflection to behave in accordance with the threat, so that what is wanted in the initial speaker (investigator or public prosecutor) becomes achieved, and second, when that interest has been fulfilled. It is hoped that a process will emerge considering a possibility when the person threatened to refuse or submit [17]. Therefore, the interrogation process established and taught through the International Criminal Investigative Training Assistance Program (ICITAP) is to place the examinee in a state of instrumental communication [18].

Based on the aspects of the critical discourse analysis approach and the trichotomy of relations, it is of course appropriate to reveal the factors of interest desired by law enforcers. If we return to the editorial section of Article 72 of the Criminal Procedure Code, of course it becomes interesting when we pay attention to the phrase "... for the benefit of his defense." The reluctance of investigators and public prosecutors to provide derivatives of the dossiers and case files is a form of representation of the fear of defeat in court. This can be seen from the explanation of the Head of Sub-Directorate for Data Processing and Public Relations of Polda Metro Jaya, Adjunct Senior Commissioner Jossie Prihambodo, that the investigation budget will not be reduced if it is not declared complete (P-21) by the Prosecutor's Office [19].

Meanwhile, in the prosecution stage, the defeat of the Public Prosecutor in a trial process will lead him to an internal evaluation process of his institution. In the end, there was the production of knowledge by the investigator and the public prosecutor to dominate the suspect / defendant or his legal adviser not to provide the derivative of the BAP for reasons that the 
researcher had previously disclosed. This domination is increasingly hegemonic when the state is dominated by - through legal norms, does not provide legal remedies, and hegemony, this knowledge is preserved as a common-sense logic from within their own institutions.

\section{Conclusion}

Investigators and Public Prosecutors, as holders of authority based on position, in exercising their power and authority based on habitus apply a model of instrumental communication to the suspect / defendant as a doxa and symbolic domination through the production of new knowledge on the meaning of Article 72 KUHAP and Article 143 paragraph (4) KUHAP. This symbolic domination is normalized as a common-sense logic based on their self-awareness of the absence of legal remedies against violations of Article 72 of the Criminal Procedure Code and Article 143 paragraph (4) of the Criminal Procedure Code. This symbolic domination is used to achieve the interests of investigators and public prosecutors in relation to absorption of the state budget and avoid defeat in court. In the end, the Criminal Procedure Code as a regulation aimed at fostering the attitude of law enforcement officials has, in essence, failed to achieve its own objectives. This is due to two things, first, the limitation of pretrial objects as a legal instrument to test the 'attitude' of law enforcers in exercising their power and authority, and second, there is a break in understanding for law enforcers as part of executive power so that they are separated from the provisions of the State Administrative Law.

\section{Acknowledgements}

Researchers would like to thank all parties, especially fellow advocates who were willing to fill out the online questionnaire. And do not forget, the researcher expressed his highest appreciation to the Dean of the Faculty of Law, University of Pancasila who has helped a lot.

\section{References}

[1] L. M. Pangaribuan, Hukum Acara Pidana. Depok: Papas Sinar Sinanti, 2013.

[2] Muladi, Kapita Selekta Sistem Peradilan Pidana. Semarang: Badan Penerbit UNDIP, 1995.

[3] A. Yuliani, "Daya Ikat Pengundangan Peraturan Perundang-Undangan," J. Legis. Indones., vol. 14, no. 04, pp. 429-438, 2017.

[4] S. Soekanto, Faktor-faktor Yang Mempengaruhi Penegakkan Hukum. Jakarta: RajaGrafindo Persada, 2014.

[5] B. Suharto, "Menyoal Sudut Pandang: Kritik Terhadap Epistemologi Positivisme Hukum," 2015, [Online]. Available: https://publikasiilmiah.ums.ac.id/bitstream/handle/11617/5678/20.Bekti Suharto.pdf? sequence $=1 \&$ isAllowed $=y$.

[6] A. Darmaji, "Herbert Marcuse tentang Masyarakat Satu Dimensi," Ilmu Ushuluddin, vol. 1, no. 6, pp. 515-526, 2013.

[7] P. Scholten, Struktur Ilmu Hukum. Bandung: Alumni, 2011.

[8] E. Utrecht and M. S. Djindang, Pengantar Dalam Hukum Indonesia. Jakarta: Pustaka Sinar Harapan, 1989.

[9] N. Schreiber Compo, A. Hyman Gregory, and R. Fisher, "Interviewing behaviors in police investigators: A field study of a current US sample," J. Psychol. Crime Law, vol. 18, no. 4, pp. 359375, 2012, doi: 10.1080/1068316X.2010.494604. 
[10] R. Marbun and E. Wijaya, "Language, Communication, and Law: Dismantling Binary Opposition in the Pre-Adjudication Sphere," no. 1, 2019, doi: 10.4108/eai.5-8-2019.2289787.

[11] LBH Jakarta, "Tanpa Didampingi Pengacara Berkas Perkara Dilimpahkan ke Pengadilan." https://bantuanhukum.or.id/tanpa-didampingi-pengacara-berkas-perkara-dilimpahkan-kepengadilan/ (accessed Feb. 03, 2021).

[12] D. A. Sastro and M. S. R., Eds., Membongkar Praktik Pelanggaran Hak Tersangka di Tingkat Penyidikan: Studi Kasus Terhadap Tersangka Kasus Narkotika di Jakarta. Jakarta: LBH Masyarakat \& Open Society Foundation, 2012.

[13] J.A. Pontier, Rechtsvinding (Penemuan Hukum). Jendela Mas Pustaka, 2008.

[14] S. Azwar, Sikap Manusia. Teori dan Pengukurannya. Yogyakarta: Pustaka Pelajar, 1995.

[15] N. Natsir, "Hubungan Psikolinguistik dalam Pemerolehan dan Pembelajaran Bahasa," J. Retorika, vol. 10, no. 1, pp. 20-29, 2017.

[16] P. Ricouer, Filsafat Wacana: Membelah Makna dalam Anatomi Bahasa. Yogyakarta: IRCiSoD, 2005.

[17] G. J. Y. Peters, R. A. C. Ruiter, and G. Kok, "Threatening communication: A qualitative study of fear appeal effectiveness beliefs among intervention developers, policymakers, politicians, scientists, and advertising professionals,” Int. J. Psychol., vol. 49, no. 2, pp. 71-79, 2014, doi: 10.1002/ijop. 12000 .

[18] S. Waljinah, "Kajian Makna Simbolik Bahasa Hukum Pada Tindakan Diskresi Polisi,” Pros. Konf. Nas. APPPTM Ke-4, vol. 3, pp. 241-250, 2013, [Online]. Available: http://asosiasipascaptm.or.id/index.php/publikasi/prosiding-konferensi-nasional-appptm-ke-4.

[19] Kompas, "Dana Operasional Polisi Terbatas." https://regional.kompas.com/read/2011/07/07/03442644/Dana.Operasional.Polisi.Terbatas?page=all (accessed Feb. 03, 2021). 